GLOBAL DEVELOPMENT AND ENVIRONMENT INSTITUTE

Working PAPER No. 09-06

\title{
Between a Rock and a Soft Place: Ecological and Feminist Economics in Policy Debates
}

\author{
Julie A. Nelson
}

June 2009

Presented at a plenary session of the United States Society for Ecological Economics conference, Washington D.C., May 31 - June 3, 2009. The author wishes to thank Frank Ackerman, Jonathan Harris, Rich Howarth, Dick Norgaard, and participants at the session at the USSEE for helpful comments.

Tufts University Medford MA 02155, USA

http://ase.tufts.edu/gdae 


\begin{abstract}
The field of ecological economics includes both economic analysis on the one hand, and discussions of values and visions for society, on the other. Using feminist insights into cultural beliefs about the relative "hardness" and "softness" of these two sides, this essay discusses how ecological economists can use this unique "between" space in order to better inform policy. The current crisis of global climate change, it is argued, requires that economists move beyond modeling and measurement, while ecological thinkers need to re-examine beliefs about markets and profit.
\end{abstract}




\title{
Between a Rock and a Soft Place: Ecological and Feminist Economics in Policy Debates
}

\author{
Julie A. Nelson
}

\section{Introduction}

Economists are increasingly in the limelight in policy discussions about the environment, and particularly in discussions about climate change. With the physical science of greenhouse gases and their effects now well established, policy discussions, at least in the United States, are focusing more and more on whether proposed mitigation or adaptation policies will be "bad for the economy." Scholars of ecological economics are often situated in the middle of this debate. On the one hand, many are trained in "hard" economic measurement, modeling, and analysis, of the sort that is being called for by many parties to these discussions. On the other hand, most people who take on the "ecological" label (as compared to "environmental" or "natural resource" labels, which are more associated with mainstream views) feel that the issues involved are in some way also bigger than what can be contained in a narrow model--that is, we believe that issues of how we connect with the rest of nature, of our values concerning justice and future generations, and of envisioning new approaches to sustainability, are involved. Speaking about visions, values, ethics, and connections, however, is culturally regarded as a relatively vague and "soft" approach.

These varied intellectual and social roots of ecological economics put ecological economists in a unique position, which holds the potential for the sorts of creative insight that can only come about from opposites held in tension. Yet good outcomes will not necessarily follow: Working from this liminal space also has its hazards. The purpose of this essay is to suggest insights from feminist economics might help ecological economists put this unique position to its best use.

\section{The Rock and the Soft Place}

What is meant by "the rock" and "the soft place" in this essay's title? The "rock" side is traditional mainstream economics, or neoclassical orthodoxy, whose proponents like to portray it as "hard," scientific and rigorous. This approach is centered on mathematically formalized theories, quantitative measurement, and econometrics. The core model is that of autonomous, rational agents maximizing utility. The orientation tends to be towards static or short-run models, and when dynamics are attempted they tend to be deterministic, or at least use known, thin-tailed probability distributions. The theoretical underpinnings of standard cost/benefit analysis (CBA), with its concept of "willingness to pay," are based in the evaluation of marginal changes. The analysis is meant to appeal to the reason and logical capacity of decision-makers. It often provides an aura of expertise and, perhaps, scientific certainty about the likely effect of policies. The goal is a rational solution to the problem created by climate externalities. 
As a result of a short-run orientation and marginalist focus, policy advice from this front--for example, from William Nordhaus (2008)--often (at least in the United States) tends to take on a gradualist, go-slow tenor. Actions are nearly always thought of in terms of legislative or regulatory government policies that, it is assumed, must be designed to create minimal "interference" with normal market and business functioning. Carbon taxes and cap-and-trade to "get the prices right" are the most-often talked about solutions, with perhaps some additional incentives for developing large-scale technologies such as carbon capture and sequestration.

Some ecological economists start from, for the most part, this side. Although such economists often break away from the usual assumptions in many ways, efforts are focused on mathematical models, measurements, and conventional policies. The emphasis is on developing better models, better measurements, and better legislative and regulatory proposals.

The "soft place" side, on the other hand, starts with a more holistic, humanistic, nature-centered, or even spiritual view. Discussions, in this case, focus around vision, ethics, care, responsibility, and community. Individual humans are seen as embedded in, or emergent from, larger wholes of society and nature. This side doesn't neglect science-in fact, it often takes inspiration from biology, the study of complexity, and the like. But as one turns to doing economics, one emphasizes the connected and community aspects of economic life. Models may take shape in words or images, and include or even emphasize humans' intuitive capacities and emotions such as love, care, and awe. The dynamic and very-long-run aspects of human interactions with the rest of nature are also central. Big changes tend to be emphasized, such as needed paradigm shifts, new eras or shifts in consciousness. Unexpected, creative, uncertain and even chaotic factors are not only accepted, but even celebrated. The analysis appeals to human feelings of connection, responsibility, love, and a desire for justice. The goal is to create new foundations for an ecologically and socially sustainable society.

As a result of the broad, long-run and global justice focuses, ecological economists coming from this side see an extremely urgent need for big changes in economic life. Actions often take the directions of attempting to inspire changes in consciousness (particularly concerning limits to through-put and consumption), build up local community initiatives, create small-scale technologies, and put more of the economy in the hands of non-profits and cooperatives. Often there is an implicit, if not explicit, level of distrust felt about large scale or mechanical technologies; and/or central governments; and/or money, markets, and for-profit businesses.

The role of ecological economists who start from this side is seen as one of being collaborators in bottom-up movements for building a new society. Although some are able to talk the language of economic theory and econometrics, a focus on short-term policy changes is felt to be too limiting. Ecological economists from the "soft side" feel a pressing need for new visions, new theories, new goals, and hope that this work will help inspire positive change. 
Individual ecological economists may, of course, identify strongly with one or the other side of this rough typology, or with parts of each. At a cultural level, however, these two approaches are, it seems, overwhelmingly thought of as widely separated and even hostile. Either one is a scientific, neutral economist, or one is a mere subjective, emotional human being, it is sometimes thought. Or: Either one is a money-grubbing defender of industrial capitalism, or one is "one of us"--part of a small, stalwart, rightthinking group seeking to save humanity and the planet. Certainly most mainstream economists see little role for discussion of ethics or holistic philosophy within serious economic analysis. Likewise some ecological philosophers and advocates have nothing good to say about business, markets, or quantification.

Is there, then, a stalemate? Or could it be that really addressing climate change requires that we have less dualistic division in our thinking, and more rethinking of the base assumptions on both sides? Could we do with more "both/and" and less "either/or"? To answer these questions, let us go back to the roots of how we, in Western contemporary culture, tend to think about nature...about gender...and about economics.

\section{Feminist Economics: Explaining How the Either/Or Got Started}

Women and nature share similar treatment in neoclassical economics. ${ }^{1}$ They are, variously, invisible; pushed into the background; treated as a "resource" for the satisfaction of male or human needs; considered to be part of a realm that "takes care of itself"; thought of as self-regenerating (or reproductive, as opposed to productive); conceived of as passive; and/or considered to be subject to male or human authority. One would search in vain in the most paradigmatic models of economics for any inkling of where the materials used in production came from, or where the detritus from the production process goes. Similarly, one would search in vain in most descriptions of human agents for a discussion of where economic agents come from, or where they go when they are broken or used up. Economic agents arrive, to quote Thomas Hobbes, “ . . as if but even now sprung out of the earth, and suddenly, like mushrooms, come to full maturity, without all kind of engagement to each other" (cited in Benhabib (1987)). The bearing and raising of children, and the care of the aged and sick--traditionally women's responsibilities--are, like nature, too unimportant to mention.

The treatment of both women and nature as passive, exploitable resources is not, however, just coincidental, or incidental to neoclassical analysis. Such thinking is part of a broader cultural way of viewing the world, with roots going far back in history. Feminist historians and philosophers of science including Evelyn Fox Keller (Keller 1985), Sandra Harding (1986), Brian Easlea (1980), and Val Plumwood (1993), brought this to light in their work during the 1980s and early 1990s. Their central point is that dualisms such as those in Table 1 have strongly influenced the Western conception of the order of the world. 
Table 1: Splitting the World: Western Philosophy

\begin{tabular}{ll}
\hline Higher Order & Lower Order \\
\hline "man" & nature \\
mind & body \\
activity & passivity \\
order & chaos \\
male & female
\end{tabular}

Such authors point out such dualisms within the philosophies of Plato, Aristotle, Thomas Aquinas, and others; show how it runs deeply within many varieties of myth and religion; and demonstrate how it permeated Enlightenment thought and the rise of modern science, through figures including Rene Descartes and Francis Bacon.

One interpretation sometimes drawn from such examples is that women really are, in some essential way, "closer to nature," and therefore are perhaps the "natural” group to take up the ecology cause and save the planet. Although there are some feminists who take this view, most do not, and instead regard such a view simply reifying old stereotypes. "Sex" is often used in the feminist literature to refer to biological differences between males and females, while "gender" refers to cultural beliefs constructed on the base of (preponderant) sexual dimorphism. ${ }^{2}$ So the issue is not whether men are more rational or less embodied than women: They manifestly are not. Rather, the point is that there is a deep cultural pattern of defining male as being opposed to, and superior to, female, and defining rationality as being opposed to, and superior to, nature, matter, and emotion.

Contemporary psychology confirms, as well, that we tend to perceive the world through "gender schemas"--that is, cognitive routines that save on mental effort by associating wide range of qualities, objects, and fields with masculinity, and others with femininity (Bem 1981; Nosek, Banaji et al. 2007). For example, sharp abstract shapes, and dogs, are often coded as masculine, while rounded abstract shapes, and cats, are mentally coded as feminine. We might call this "cognitive gender." While such mental shortcuts often harmlessly speed up our thinking, they can also severely limit and bias our thinking.

Other traits and concepts, beyond those mentioned above, also show this sort of patterning. In particular, in the early 1990s, feminist economists began to notice that the definition, models, and methods of mainstream economics followed just such a gender schematic pattern, as shown in Table 2. 
Table 2: Splitting the World: Gender Schemas in Neoclassical Orthodoxy

\begin{tabular}{cl}
\hline \multicolumn{1}{c}{ Economics ("Hard") } & Not Economics ("Soft") \\
\hline Definition: & nonmarket \\
markets & bodily experience \\
mental choice & abundance \\
scarcity & relatedness \\
Model: & interdependence \\
individuality & other-interest \\
$\quad$ autonomy & emotion \\
self-interest & \\
rationality & qualitative \\
Methods: & verbal or intuitive \\
$\quad$ quantitative & normative \\
formal & subjective \\
positive & particular \\
general & \\
Gender: & feminine \\
masculine &
\end{tabular}

That is, when mainstream economics is defined as the study of either markets or choice, non-market and bodily experience are neglected. The model of "economic man" is of a autonomous, rational, self-interested actor; all interdependencies and emotions are excluded. Even more than topic matter, methodology is often used to demarcate what is or isn't economics: Quantitative mathematical models and empirical studies that aspire to a value-free neutrality have the high prestige. Qualitative study and issues of ethics, or any discussion of one's standpoint or position, are strenuously avoided. The cultural and cognitive gender associations are clearly "masculine" and "hard" for the left column, and "feminine" and "soft" for the right. We might diagram this perceived relationship between gender and value as shown in Figure 1: masculinity is hard, superior, and virile; femininity is associated with softness, inferiority, and emasculation.

\section{Figure 1: The Hierarchical Gender Dualism}

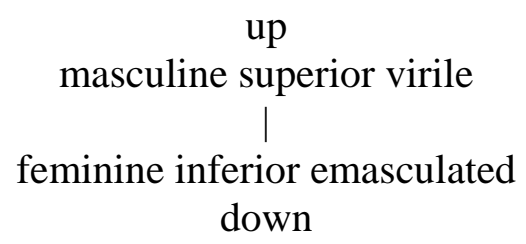

These common habits of thinking tend to suggest that it is "masculine" and "superior" to see ourselves as beings who are above nature, and that doing "good economics" means distancing ourselves from each other and from ethical concerns. One 
way of trying to fight this paradigm might be to simply turn the tables, and value everything in the "soft" column over everything in the "hard" column. That is, the only alternative may seem to be to see the world in purely "holistic" terms, rejecting notions of individuality and rationality in favor of immersion in experience. Markets and quantitative analysis may be rejected as well, as essentially oppressive structures. Flipping the chart in this way, however, does not challenge the dualism: It simply substitutes one distinctly partial view of the world with another.

\section{Feminist Economics: Getting to Both/And}

But a number of feminist philosophers and feminist economists have suggested a different solution: Deconstructing the dualism itself. "A transformative feminism," writes ecofeminist philosopher Karen Warren (1987, 19, emphasis added), would involve a psychological restructuring of our attitudes and beliefs about ourselves and 'our world' (including the nonhuman world), and a philosophical rethinking of the notion of the self such that we see ourselves as both co-members of an ecological community and yet different from other members of it.

That is, instead of accepting the old either/or, perhaps we can get to a more nuanced and helpful both/and.

As a tool for developing this more flexible sort of thinking, a "gender-value compass” (Nelson 1992; Nelson 1996) may be useful. Consider how the hierarchy pictured in Figure 1, for example, changes if one refuses this overlay, and instead splits off the gender axis from the value axis, as shown in Figure 2:

Figure 2:

Positive

\begin{tabular}{ll|l} 
& $\begin{array}{l}\text { M+ } \\
\text { virility }\end{array}$ & $\begin{array}{l}\mathrm{F}+ \\
\text { muliebrity }\end{array}$ \\
\cline { 2 - 3 } Masculine & $\begin{array}{l}\mathrm{F}- \\
\text { emasculation }\end{array}$
\end{tabular}

Negative

Virility is defined in the dictionary as "manly vigor.” Emasculation is the lack thereof. But are all things feminine just degraded forms of masculine characteristics? If one looks hard enough in a sufficiently thick dictionary (or is persistent in web searching), one can also find the new term in the figure. "Muliebrity" is defined as "womanliness," "possessing full womanly powers," or "the feminine correlative of 
virility." While not a term in common use, it suggests that alongside and on a par with a masculine, positive strengths we might also consider there to be feminine, positive strengths. The cross-diagonal terms illustrate a condition of lack: for example, "emasculation” is an absence of "virility." There is, unfortunately, currently no term in the English language for a lack of womanly vigor.

Applying this sort of analysis to the relationship between individual humans and nature (and between individual humans and society), we can think of people as being both individuated and connected, as illustrated in Figure 3. The masculine extreme or "separative" version (Nelson 1995; England 2003) overemphasizes the aspects that make people different from each other, and human consciousness different from the rest of nature. The feminine extreme or "soluble" version overemphasizes connection and continuity, to the exclusion of individual or distinctive will, activity, or identity. Yet we are a part of nature and constituted in our relationships, as well as able to think and act as human beings and individuals.

Figure 3

\begin{tabular}{l|l}
$\begin{array}{l}\mathrm{M}+ \\
\text { individual }\end{array}$ & $\begin{array}{l}\mathrm{F}+ \\
\text { related }\end{array}$ \\
\hline $\begin{array}{l}\mathrm{M}- \\
\text { separative }\end{array}$ & $\begin{array}{l}\mathrm{F}- \\
\text { soluble }\end{array}$
\end{tabular}

The two negative quadrants of the diagram form a negative complementarity: Mr. John Jones--imagined to be autonomous and independent--is represents the myth of the separative self while Mrs. John Jones--whose own name is lost--represents the soluble extreme. The two positive quadrants represent a positive complementarity: individualsin-relation.

We can also examine the idea that we have an either/or choice between masculine, precise, quantitative methods and less precise qualitative analysis. Figure 4 suggests that there are costs to focusing only on precision, and benefits to be had by a richer approach.

\section{Figure 4}

\begin{tabular}{l|l}
$\begin{array}{l}\text { M+ } \\
\text { precise } \\
\text { elegant }\end{array}$ & $\begin{array}{l}\mathrm{F}+ \\
\text { rich, } \\
\text { realistic }\end{array}$ \\
\hline $\begin{array}{l}\text { M- } \\
\text { unrealistic, } \\
\text { thin }\end{array}$ & $\begin{array}{l}\text { F- } \\
\text { imprecise, } \\
\text { vague }\end{array}$
\end{tabular}


That is, the weakness of overly precise analysis is that it becomes thin and unrealistic. What is taken as a sign of "rigor," may often be more like "rigor mortis." Analysis that aims to be rich and realistic, but forgets about precision, can end up being simply vague. Good analysis aims at useful combinations of precision and richness.

Even the terms "hard" and "soft" can be deconstructed this way. Hardness is usually associated with strength, but it can also mean rigidity, a illustrated in Figure 5. Softness can mean weakness, but it can also indicate flexibility. A research program that is rigid and weak is brittle, and breaks under the first criticism or adjustment to an assumption. One that is strong and flexible is resilient, and can adapt to meet new situations.

\section{Figure 5}

\begin{tabular}{l|l}
$\begin{array}{l}\text { M+ } \\
\text { hard, } \\
\text { strong }\end{array}$ & $\begin{array}{l}\mathrm{F}+ \\
\text { soft, } \\
\text { flexible }\end{array}$ \\
\hline $\begin{array}{l}\text { M- } \\
\text { hard, } \\
\text { rigid }\end{array}$ & $\begin{array}{l}\text { F- } \\
\text { soft, } \\
\text { weak }\end{array}$
\end{tabular}

Two more points from the feminist analysis are relevant to the discussion of ecological economics. First, there is the question of "objectivity." Hierarchical, dualistic thinking also creates the following false "either/or" choice: either one does work committed to social betterment or one does work that is scientifically objective. Feminist scholars of science have revealed the sexist biases implicit in the belief that objectivity is a matter of detachment. Feminist alternatives, such as those called "strong objectivity" by Harding (1986), “dynamic objectivity” Keller (Keller 1985, 116), or "positional objectivity" by economist Amartya Sen (Sen 1992) incorporate a more relational approach. For example, as expressed by feminist philosopher Helen Longino, “The objectivity of individuals...consists in their participation in the collective give-and-take of critical discussion and not in some special relation (of detachment, hardheadedness) they may bear to their observations” $(1990,79)$.

Second, there is the question of the definition of the field of economics. Regarding subject matter, a definition of economics that does not rely on either a masculine-biased definition based on markets and business firms, or a masculine-biased definition based on rational choice theory, is one based on provisioning: Economics is about how societies organize themselves to provide for the survival and flourishing of life (Nelson 1993). Many ecological economists already use this definition or something like it; others, however, still adhere to markets or scarcity. 
So, if the world is not in its essence divided between rocks and soft places, but instead includes both, what does that mean for our analysis as ecological economists?

\section{Starting from the Rock}

Some fissures are beginning to appear in critical parts of the "rock" of "hard" economic analysis of climate change. As strenuously as they might try to avoid the fact, some mainstream economists are coming to realize that they need at least some bits of the "soft" side if they are to act as responsible human beings in this time of climate crisis.

The most notable case of this, of course is that of Nicholas Stern, former Chief Economist of the World Bank, and lead author of the United Kingdom Treasury's Stern Review on the Economics of Climate Change (Stern 2006). While his mainstream credentials are impeccable, and his Review made use of a great deal of modeling, he is currently quite vocal about the limitations of conventional economic analysis. Ethics and uncertainty, as well as international policy, must be "at the core" of any analysis, according to Stern (Stern 2008, 2). Marginal analysis can at best be "supplementary" to analysis, which must be complemented with understandings of "economic history...country studies and particular studies of the context and issues in question" (Stern 2008, 3). These positions, of course, challenge the gendered dualisms just reviewed on a number of dimensions.

Martin Weitzman's recent work does not go as far as Stern's in accepting the necessity of a both/and approach, but he does bridge parts of the divide. Weitzman claims that "the incredible magnitude of the deep structural uncertainties that are involved in climate change analysis" can no longer be ignored, and introduces fat-tailed probability distributions into Integrated Assessment Models (IAM) to account for it (Weitzman 2009, 18). While the mathematical model is "rock" style, the centrality of uncertainty is novel, and some of his other assumptions, conclusions, and reflections also come from the "soft place." Weitzman openly uses terms like "raw intuition" $(14)$ and "subjective" $(18,19)$ to describe views he nevertheless strongly holds. He arrives at a prescription of more emphatic action than many of his modeling colleagues. And he is critical of standard modeling in ways that many ecological economists will find familiar, criticizing them for "misplaced concreteness" (18), pretensions to precision where precision is not possible (18), and "deluding ourselves and others" with results characterized by an "artificial crispness." He also distances himself from the usual implicit idea that conventional models incorporate self-evident eternal truths: He refers to utility theory as a human creation- - the discipline-imposing form of (present discounted) expected utility theory" (1-2, emphasis added) — and explains economist's loyalty to some aspects of modeling in emotional terms — "the comfort that economists feel" with them (16).

Weitzman continues, however, to emphatically disdain any role for ethics in economic analysis, characterizing the Stern Review's choice of discount rate as paternalistic, and putting the term "ethics" in scare quotes whenever he uses it (Weitzman 
2007; Weitzman 2009). ${ }^{3}$ His recommendations for action run more towards large-scale bioengineering than towards social change (17). He still also feels obliged, in his last words, to claim exactness and rigor for his analysis (18). But there is an important admission, here, however small, that the tools of "hard" analysis alone are not up to the job of addressing climate change.

Even Richard Tol, who has been a vocal defender of Nordhaus-style "go slow" prescriptions (2009), has noticed that the policy prescriptions arising from the most popular IAMs do not correspond to what he believes actually needs to be done. For example, in one recent article--after reviewing the results of models run by himself, Nordhaus, and others--Richard Tol (2008) writes:

Nonetheless, the policy suggested by cost-benefit analysis - emission reduction, but not enough to stabilize emissions let alone concentrations is intuitively wrong. It cannot be the case that the best policy is to let the world get warmer and warmer and warmer still... [c]ommon sense suggests that climate change should be stopped at a lower level. Our best estimates challenge the common sense, but it is as yet unclear whether our research findings are superior to our gut feelings. (439, emphasis added)

The rest of the article goes back and forth between parts which, in accord with Tol's intuition, lean towards faster policy changes and concern with equity, and parts which show a pronounced allegiance to "hard-nosed neo-classical" (439) methodology and a view of the economist as neutral observer bound to observe the "reality" of decisionmakers' tendency to follow selfish interests. While he remains mostly on the vocal "go slow" side, he gives a slight indication here, at least, that perhaps the "hard" models are not the last word.

If fissures such as those opened by Stern, and to some extent Weitzman (and possibly Tol), could widen into a chink, and then a gap, perhaps more "hard" researchers will come to see the necessity of allowing for, and valuing, the side of the world stereotyped as "soft," and accepting that one cannot be an economist without being a human as well.

Would it helpful to accept these larger values, and then, since we are trained as economics, to continue generating our usual IAM models or CBA studies-that is, continue to aspire to "build a better model"? Some will argue that standard, marginalist CBA or cost-effectiveness analysis can still play a central role in determining the most efficient way to reach goals, once proper climate change goals have been set by social and ethical discussion. There are reasons, however, to doubt that this may not be the most effective way to use economists' energies right now, if we are to deal adequately with the climate crisis.

The first reason is that the core assumptions of the models themselves emphasize things that may, at this point in history, be more distracting than helpful. Efficiency 
concerns, central to such modeling, are, in the present case, of second order importance at best. The models emphasize small changes, monetary valuation, individual-self interest, and individual utility from consumption--all of which tend to take us in exactly the wrong direction. A narrow focus on marginalist modeling may serve to dangerously detract economists, policymakers', and the public's attention from the more important questions of equity, large changes, and community. In a more balanced future world, perhaps, CBA will have given up its pretense to sole scientific prestige, and efficiency taken its place as one among many social goals. For this to come to pass, however, the tools of formalization, measurement, and modeling would need to be recognized as particular tools--tools that are helpful for some tasks and not for others. Such humility seems hard to come by: Economists equipped with the elegant "hammers" of modeling and econometrics often tend to "see any problem as a nail." In the meantime, the basic assumptions of conventional welfare economics simply strike the wrong chord.

Second, the fact that models are extremely sensitive to the specification of assumptions, and very dependent on projections of a radically uncertain future, makes them very easy to misuse in policy evaluation. For example, there is a disturbing tendency on the part of some environmental groups to want, from economists, "studies" that show that preventing climate change will be "good for the economy" in terms of GDP growth, and will not change people's lives very much. One could, of course, by suitably upping the technology parameters, for example, provide such models. And these could, arguably, by proper dissemination around the Hill, be useful in getting some climate change legislation passed. Such an approach, however, would sacrifice more important long-term goals for rather minor short-term gains. No one who takes the longrun climate change science seriously believes that the problem would be adequately addressed by the rather modest sorts of legislation currently considered politically viable. No one who takes issues of global environmental justice seriously believes that the patterns of consumption, transportation, and residence of those in the rich parts of the world can continue more or less unchanged.

Not only would a short-term, "better model" strategy potentially destroy the credibility of ecological economics--as people figure out, in the longer term, that they were offered false hopes - there is also evidence that it might not be as effective as other tactics. The "better model" strategy relies on the "rock"-side political assumptions that people are self-interested and rational, and take measured steps towards well-thought-out goals. It assumes that policymaking is actually a reasoned process in which legislators try to decide what is best for their constituents. While as academics we are often biased towards thinking of people as rational, considerable evidence tells us that this is not how important policies are enacted. Consider how, until recent elections, low- and middleincome people consistently voted against their own economic self-interest in electing Republican leadership. George Lakoff's book Don't Think of an Elephant (2004) is a damning critique of the use of technocratic self-interest language by Democrats in the United States, that allowed the Republicans a free hand in framing their proposals around the more mobilizing grounds of values, national identity, and emotional security. Consider Afghanistan and Iraq. No one in the United States Congress demanded a 
detailed cost-benefit analysis of each aspect of these policies, before authorizing funds. When matters of national pride, and (in these cases, somewhat irrational and debilitating) fear--emotional issues from the "soft" side of the cultural dualism--are foremost, the leaders wanting a policy know that the person-as-consumer will yield the front seat to the person-as-citizen or person-who-wants-security. Emotional mobilization based on fear can, of course, be dangerous, and lead to rising fascism. But using this as an excuse to dismiss all emotional and value-based motivations is short-sighted. What we need in regard to climate change is not another model, but a mobilization on the order of going to war...only much bigger.

Economists skilled in these areas can serve an important role in pointing out exactly how biased and assumption-sensitive the economic models prescribing slow changes are, and so help debunk the idea that policymakers should accept their solutions as representing good science. We can show that the existing models are bad models. But this negative role is the major thing this approach can contribute.

"Rock" side ecological economists will not be terribly happy with the idea of backing away from the usual tools. There is a natural human inclination to want to put one's skills, in which one has deeply invested, to good use. We teach our undergraduates, however, that rational decision making requires ignoring sunk costs — that is, past resource allocations that are now "water under the bridge." Rational decision-making, we say, means moving on to see a problem in terms of current and future issues. At this point in our history, and facing the particular problem of climate change, economists need to recognize that our modeling and econometric skills, however hard-earned, may not be what the world most needs right now.

On the issue of climate change, "rock" people need to recognize the limits of traditional tools, recognize the unity of being both human and scholarly, and be ready to speak out more, on a gut level, about values, visions, the need for big changes, and the importance of human and ecological community.

\section{Starting from the Soft Place}

The fact that "rock" people need to move towards being more "soft" does not, however, mean that the "soft" people were right all along. The feminist analysis presented earlier suggests that being one-sided along "soft" lines is no great improvement, but rather a continuation of old dualisms from just another angle.

The flaw in "soft place" analysis that is most relevant to climate change policy is in the attitude often taken towards money, profit, business, competition, and markets. Or, to put it more in the lingo of the field: towards the system of global industrial corporate capitalism. It is no exaggeration to say that in much of this literature, global industrial corporate capitalism is seen as a monolithic enemy, and the sole cause of environmental and social degradation. The alternative envisioned, then, it seems, must 
differ on every point: The new society must be local, back-to-nature, non-profit, and cooperative.

Those who take this flip-side approach are actually, in an important sense, dyedin-the-wool neoclassical economists--Friedmanites, if you will. Major tenants of neoclassical orthodoxy include:

- People are purely self-interested in their economic dealings.

- Businesses are all about making profits.

- The laws of markets are inexorable, like the laws of physics.

- Social and ethical aspects of humanity belong to a realm separate from business and markets.

If one assumes that commercial life is intrinsically mechanical and anti-social then the idea of "socially and environmentally responsible corporations" is an oxymoron. Any sign of pro-environmental action can be dismissed as so much "greenwashing." Milton Friedman once famously said, "Few trends could so thoroughly undermine the very foundations of our free society as the acceptance by corporate officials of a social responsibility other than to make as much money for their stockholders as possible” (1982, 133). Replace "free society" with "oppressive society," and the extreme softsiders would agree unequivocally that this is the way that modern capitalism works.

But is it?

Feminist analysis--as well as analysis from law, history, and elsewhere-demonstrates that this dualism between "hard" economics and "soft" society is wildly overblown. In fact, the notion that firms maximize profits was not derived from careful study of business behavior. Rather, it was invented by neoclassical economists because it gives the illusion that firm behavior can be adequately analyzed using the tools of calculus. ${ }^{4}$ The assumption of profit maximization "lent an attractive patina of scientific rigor," writes legal scholar Lynn A. Stout, to the study of corporations. It entered popular discourse because the business press found that it offered "an easy-to-explain, sound-bite description" of what corporations are and do (2005, 4-5). If, on the other hand, the economy is actually part of society, and business firms are--like other organizations-made up of actual human people with a variety of goals, feelings, values, and abilities, then perhaps the goal of social and environmental responsibility need not be so quickly dismissed.

The belief that firms are mechanical profit-maximizers, however, can be hard to overcome. Many believe, for example that profit maximization is mandated by law. But an actual examination of the relevant state legal codes shows that it is not so. Corporate codes usually simply state that a corporation's purpose is to engage in business or trade. In the section on formation and purposes in the most commonly used corporate codes (those of the state of Delaware) the words "profit" or "return to shareholders" are nowhere mentioned. Case law doesn’t require it, either. While the directors and 
managers of corporations have a "fiduciary duty" (duty of loyalty or care) to the corporation, this duty is not limited to shareholders or profits. Legal scholars note that in the contemporary United States, "each state implicitly recognizes that a broader group of interests may be considered," such as those of employees, customers, creditors, and local communities (Adams and Matheson 2000, 1088). A diverse understanding of obligations is also found among corporate directors themselves. One survey found that only a minority of directors felt obligated only to shareholders; most directors feel obligated to more than one constituency. ${ }^{5}$ Making a good faith effort to earn profits is, indeed, one of the important responsibilities of a business manager. But achieving the highest profit without regard to any other goal is not required by law.

If the law doesn't require a relentless focus on profits, it this perhaps forced by "market discipline”? Many believe that the pressures of competitive markets will sooner or later drive all companies that are not ruthless profit-maximizers out of business. And, indeed, parts of the global economy are highly competitive. Clothing subcontractors dealing with large branded companies or major retailers, for example, have to compete fiercely with each other. But Wal-Mart, Exxon Mobil, Verizon, UPS, Microsoft and the like are hardly the sort of anonymous, powerless companies that populate the neoclassical theory of perfect competition. The economic conditions they face do not dictate their decisions to them: they run with some "slack" and room for discretion. Now, the question is what the leaders of such companies choose to do with the difference between revenues and strictly necessary costs. The leaders can choose to increase compensation and perks for executives, lobby for laws that benefit only them, and so on-actions that may contribute little to (or even diminish) long-run shareholder wealth. Sound familiar? Or the leaders of a company running with some slack can choose to invest in green technology, check that its subcontractors comply with environmental standards, and take initiative on conservation. There is no legal or economic "mechanism" that dictates that corporate leaders have to go one way or the other. Corporate leaders face choices--moral choices. Some of them, in fact, are humans beings who worry whether the world will be a good place for their grandchildren.

Feminist scholarship also reminds us that small, local, organizations not dedicated to profit are not necessarily well-behaved. While many theorists idealize "the family" as the heart of love and connection, for example, feminists are only too aware of the women and children crowding domestic violence shelters.

A "both/and" view of business and markets sees in them both potential for great harm, and potential for good. In part, what results from business behavior is a result of the laws and institutions that create the framework for commerce. As we have seen in the ongoing financial crisis, in some places our systems of social oversight have been much too weak, and policymakers have put far too much trust in the role of self-policing. But the results are also in part a result of what people in business themselves, believe themselves to be doing. To the extent that neoclassical orthodoxy and "soft place" critics both insist that business leaders value monetary returns over everything else, they can hardly be blamed for doing what we say. 
From a policy point of view, extreme "soft place" approaches tend to be very local, or very utopian. One can sometimes make changes at a town or regional level. One can take hope in small victories. Those that imagine that nothing short of the complete dismantling of the entire system of global industrial corporate capitalism will save the earth, however, seem to talk more to each other, than to policymakers. Even when the message about damage done by the corporate monolith gets the sympathy of an average (probably corporate-employed) American, it may leave them feeling simply overwhelmed. Sometimes the analysis is also quite backward-looking, romanticizing a rural lifestyle and pure wilderness aesthetic when, in fact, the most sustainable way of supporting humans and other species into the future may include taking advantage of a number of urban and industrial innovations.

On the issue of climate change, treating corporations as irremediable enemies takes us in exactly the wrong direction. In formulating effective responses to this problem, "soft place" people need to recognize the narrowness of an analysis that treats businesses and markets as radically separate from society and ethics. We need to recognize our common humanity with corporate leaders, and support movements towards both a greater social role in directing business and investment, and greater social and environmental responsibility by those in positions of private-sector leadership. There needs to be no less insistence on the ethical, caring, and life-preserving mandates for addressing climate change, and the size of the social and ethical changes needed to get to true sustainability. But it is also necessary to more rigorously question dogmas that tell us we live in a split world.

\section{Conclusion: Between a Rock and a Soft Place}

As ecological economists, we are uniquely situated to play an important role in environmental, and especially climate change, debates. Our skills in discussing the economy put us directly into the policy fray. Our ecology-sustaining goals make us look towards long-term and transformative solutions. Bringing these together, we can, if we choose, become leaders in envisioning and building a new economic foundation for sustainable human and biospheric communities. If, however, we hold on tightly to our macho traditional methods on the one hand, or, on the other hand, to our rejection of the sphere of commerce, we may lose our chance.

We are, indeed, between a rock and a soft place. Feminist analysis suggests that there is tremendous dynamic energy to be found in embracing the tensions of our unique location. Can we proceed with an attitude of "both/and" rather than "either/or"? 
Julie A. Nelson is a Senior Research Fellow at the Global Development and Environment Institute at Tufts University and an Associate Professor of Economics at the University of Massachusetts, Boston; inquiries can be directed to Julie.Nelson@tufts.edu 


\section{REFERENCES}

Adams, Edward S. and John H. Matheson (2000). "A Statutory Model for Corporate Constituency Concerns." Emory Law Journal 49: 1085-1135.

Bem, Sandra Lipsitz. (1981). "Gender Schema Theory: A Cognitive Account of Sex Typing." Psychological Review 88(4): 354-364.

Benhabib, Seyla (1987). The generalized and concrete other: The Kohlberg-Gilligan controversy and feminist theory. Feminism as Critique: On the Politics of Gender. S. Benhabib and D. Cornell. Minneapolis, University of Minnesota Press.

Easlea, Brian (1980). Witch Hunting, Magic and the New Philosophy: An Introduction to Debates of the Scientific Revolution, 1450-1750. Atlantic Highlands, NJ, Humanities Press.

England, Paula (2003). Separative and Soluble Selves: Dichotomous Thinking in Economics. Feminist Economics Today: Beyond Economic Man. M. A. Ferber and J. A. Nelson. Chicago, University of Chicago Press: 33-59.

Ferber, Marianne A. and Julie A. Nelson, Eds. (1993). Beyond Economic Man: Feminist Theory and Economics. Chicago, University of Chicago Press.

Ferber, Marianne A. and Julie A. Nelson, Eds. (2003). Feminist Economics Today. Chicago, University of Chicago Press.

Friedman, Milton (1982). Capitalism and Freedom. Chicago, University of Chicago Press.

Harding, Sandra (1986). The Science Question in Feminism. Ithaca, Cornell University Press.

Keller, Evelyn Fox (1985). Reflections on Gender and Science. New Haven, Conn., Yale University Press.

Lakoff, George (2004). Don't Think of an Elephant! Know Your Values and Frame the Debate. White River Junction, VT, Chelsea Green.

Longino, Helen (1990). Science as Social Knowledge: Values and Objectivity in Scientific Inquiry. Princeton, NJ, Princeton University Press.

Nelson, Julie A (1993). The Study of Choice or the Study of Provisioning? Gender and the Definition of Economics. Beyond Economic Man. M. Ferber and J. A. Nelson. Chicago, University of Chicago Press: 23-36.

Nelson, Julie A. (1992). "Gender, Metaphor, and the Definition of Economics." Economics and Philosophy 8: 103-125.

Nelson, Julie A. (1995). "Feminism and Economics." Journal of Economic Perspectives 9(2): 131-148.

Nelson, Julie A. (1996). Feminism, Objectivity and Economics. London, Routledge.

Nelson, Julie A. (1997). "Feminism, Ecology and the Philosophy of Economics." Ecological Economics 20: 155-162.

Nelson, Julie A. (2006). Economics for Humans. Chicago, University of Chicago Press.

Nelson, Julie A. (2008). "Economists, Value Judgments, and Climate Change: A View From Feminist Economics." Ecological Economics 65(3): 441-447.

Nordhaus, William D. (2008). A Question of Balance: Weighing the Options on Global Warming Policies. New Haven, Yale University Press. 
Nosek, Brian, Mahzarin Banaji, et al. (2007). "'Gender-Science IAT"." from https://implicit.harvard.edu/implicit/.

Plumwood, Val (1993). Feminism and the Mastery of Nature. London, Routledge.

Sen, Amartya (1983). "The Profit Motive." Lloyds Bank Review(147): 1-20.

Sen, Amartya (1992). Objectivity and Position. The Lindley Lecture, University of Kansas.

Smith, G. (1998). "The Shareholder Primacy Norm." The Journal of Corporate Law Winter.

Stern, Nicholas (2008). "The Economics of Climate Change." American Economic Review 98(2): 1-37.

Stern, Sir Nicholas (2006). Stern Review on the Economics of Climate Change. London, HM Treasury.

Stout, Lynn A. (2005). New Thinking On 'Shareholder Primacy'. Working Paper, University of California at Los Angeles School of Law.

Tol, Richard S. J. (2008). "Why Worry About Climate Change? A Research Agenda." Environmental Values 17: 437-470.

Tol, Richard S. J. (2009). "The Economic Effects of Climate Change." Journal of Economic Perspectives 23(2): 29-51.

Warren, Karen J. (1987). "Feminism and ecology: Making connections." Environmental Ethics 9: 3-20.

Weitzman, Martin L. (2007). "A Review of the Stern Review on the Economics of Climate Change." Journal of Economic Literature 45(3): 703-724.

Weitzman, Martin L. (2009). "On Modeling and Interpreting the Economics of Catastrophic Climate Change." The Review of Economics and Statistics 91(1): 119. 


\section{NOTES}

${ }^{1}$ For a fuller discussion of these issues, see Nelson (1997). For introductions to feminist economic analysis for those unfamiliar with the field, see Ferber and Nelson (1993; 2003).

${ }^{2}$ Recent feminist literature has become more complicated as scholars deal with intersexuality, transsexuality, and the like. But the sex/gender distinction provides a rough typology that is useful when examining cultural stereotypes.

${ }^{3}$ For a longer discussion of this point, see Nelson(2008)

${ }^{4}$ For more on this, see Nelson (2006)

${ }^{5}$ Jay W. Lorsch and Elizabeth Maciver, Pawns or Potentates (1989) as cited in D. Gordon Smith (1998,

291). See also the discussion in Sen (1983). 
The Global Development And Environment Institute (GDAE) is a research institute at Tufts University dedicated to promoting a better understanding of how societies can pursue their economic goals in an environmentally and socially sustainable manner. GDAE pursues its mission through original research, policy work, publication projects, curriculum development, conferences, and other activities. The "GDAE Working Papers" series presents substantive work-in-progress by GDAE-affiliated researchers. We welcome your comments, either by e-mail directly to the author or to G-DAE,

Tufts University, 44 Teele Ave., Medford, MA 02155 USA; tel: 617-627-3530; fax: 617-627-2409; e-mail: gdae@tufts.edu; website: http://ase.tufts.edu/gdae.

\section{Papers in this Series:}

00-01 Still Dead After All These Years: Interpreting the Failure of General Equilibrium Theory (Frank Ackerman, November 1999)

00-02 Economics in Context: The Need for a New Textbook (Neva R. Goodwin, Oleg I. Ananyin, Frank Ackerman and Thomas E. Weisskopf, February 1997)

00-03 Trade Liberalization and Pollution Intensive Industries in Developing Countries: A Partial Equilibrium Approach (Kevin Gallagher and Frank Ackerman, January 2000)

00-04 Basic Principles of Sustainable Development (Jonathan M. Harris, June 2000)

00-05 Getting the Prices Wrong: The Limits of Market-Based Environmental Policy (Frank Ackerman and Kevin Gallagher, September 2000)

00-06 Telling Other Stories: Heterodox Critiques of Neoclassical Micro Principles Texts (Steve Cohn, August 2000)

00-07 Trade Liberalization and Industrial Pollution in Mexico: Lessons for the FTAA (Kevin Gallagher, October 2000) (Paper withdrawn- see www.ase.tufts.edu/gdae/ for details)

00-08 Waste in the Inner City: Asset or Assault? (Frank Ackerman and Sumreen Mirza, June 2000)

01-01 Civil Economy and Civilized Economics: Essentials for Sustainable Development (Neva Goodwin, January 2001)

01-02 Mixed Signals: Market Incentives, Recycling and the Price Spike of 1995. (Frank Ackerman and Kevin Gallagher, January 2001)

01-03 Community Control in a Global Economy: Lessons from Mexico’s Economic Integration Process (Tim Wise and Eliza Waters, February 2001)

01-04 Agriculture in a Global Perspective (Jonathan M. Harris, March 2001)

01-05 Better Principles: New Approaches to Teaching Introductory Economics (Neva R. Goodwin and Jonathan M. Harris, March 2001)

01-06 The \$6.1 Million Question (Frank Ackerman and Lisa Heinzerling, April 2002)

01-07 Dirt is in the Eye of the Beholder: The World Bank Air Pollution Intensities for Mexico (Francisco Aguayo, Kevin P. Gallagher, and Ana Citlalic González, July 2001)

01-08 Is NACEC a Model Trade and Environment Institution? Lessons from Mexican Industry (Kevin P. Gallagher, October 2001)

01-09 Macroeconomic Policy and Sustainability (Jonathan M. Harris, July 2001) 
02-01 Economic Analysis in Environmental Reviews of Trade Agreements: Assessing the North American Experience. (Kevin Gallagher, Frank Ackerman, Luke Ney, April 2002)

03-01 Read My Lips: More New Tax Cuts-The Distributional Impacts of Repealing Dividend Taxation (Brian Roach, February 2003)

03-02 Macroeconomics for the $21^{\text {st }}$ Century (Neva R. Goodwin, February 2003)

03-03 Reconciling Growth and the Environment (Jonathan M. Harris and Neva R. Goodwin, March 2003)

03-04 Current Economic Conditions in Myanmar and Options for Sustainable Growth (David Dapice, May 2003)

03-05 Economic Reform, Energy, and Development: The Case of Mexican Manufacturing (Francisco Aguayo and Kevin P. Gallagher, July 2003)

03-06 Free Trade, Corn, and the Environment: Environmental Impacts of US-Mexico Corn Trade Under NAFTA

03-07 Five Kinds of Capital: Useful Concepts for Sustainable Development (Neva R. Goodwin, September 2003)

03-08 International Trade and Air Pollution: The Economic Costs of Air Emissions from Waterborne Commerce Vessels in the United States (Kevin P. Gallagher and Robin Taylor, September 2003)

03-09 Costs of Preventable Childhood Illness: The Price We Pay for Pollution (Rachel Massey and Frank Ackerman, September 2003)

03-10 Progressive and Regressive Taxation in the United States: Who's Really Paying (and Not Paying) their Fair Share? (Brian Roach, October 2003)

03-11 Clocks, Creation, and Clarity: Insights on Ethics and Economics from a Feminist Perspective (Julie A. Nelson, October 2003)

04-01 Beyond Small-Is-Beautiful: A Buddhist and Feminist Analysis of Ethics and Business (Julie A. Nelson, January 2004)

04-02 The Paradox of Agricultural Subsidies: Measurement Issues, Agricultural Dumping, and Policy Reform (Timothy A. Wise, February 2004)

04-03 Is Economics a Natural Science? (Julie Nelson, March 2004)

05-01 The Shrinking Gains from Trade: A Critical Assessment of Doha Round Projections (Frank Ackerman, October 2005)

05-02 Understanding the Farm Problem: Six Common Errors in Presenting Farm Statistics (Timothy A. Wise, March 2005)

05-03 Securing Social Security: Sensitivity to Economic Assumptions and Analysis of Policy Options (Brian Roach and Frank Ackerman, May 2005)

05-04 Rationality and Humanity: A View from Feminist Economics (Julie A. Nelson, May 2005)

05-05 Teaching Ecological and Feminist Economics in the Principles Course (Julie A. Nelson and Neva Goodwin, June 2005)

05-06 Policy Space for Development in the WTO and Beyond: The Case of Intellectual Property Rights (Ken Shadlen, November 2005)

05-07 Identifying the Real Winners from U.S. Agricultural Policies (Timothy A. Wise, December 2005)

06-01 The Missing Links between Foreign Investment and Development: Lessons from Costa Rica and Mexico (Eva A. Paus and Kevin P. Gallagher, February 2006)

06-02 The Unbearable Lightness of Regulatory Costs (Frank Ackerman, February 2006) 
06-03 Feeding the Factory Farm: Implicit Subsidies to the Broiler Chicken Industry (Elanor Starmer, Aimee Witteman and Timothy A. Wise, June 2006)

06-04 Ethics and International Debt: A View from Feminist Economics (Julie A. Nelson, August 2006)

06-05 Can Climate Change Save Lives? (Frank Ackerman and Elizabeth Stanton, September 2006)

06-06 European Chemical Policy and the United States: The Impacts of REACH (Frank Ackerman, Elizabeth Stanton and Rachel Massey, September 2006)

06-07 The Economics of Inaction on Climate Change: A Sensitivity Analysis (Frank Ackerman and Ian J. Finlayson, October 2006)

07-01 Policy Space for Mexican Maize: Protecting Agro-biodiversity by Promoting Rural Livelihoods (Timothy A. Wise, February 2007)

07-02 Declining Poverty in Latin America? A Critical Analysis of New Estimates by International Institutions (Ann Helwege and Melissa B.L. Birch, September 2007)

07-03 Economists, Value Judgments, and Climate Change: A View From Feminist Economics (Julie A. Nelson, October 2007)

07-04 Living High on the Hog: Factory Farms, Federal Policy, and the Structural Transformation of Swine Production (Elanor Starmer and Timothy A. Wise, December 2007)

07-05 The Politics of Patents and Drugs in Brazil and Mexico: The Industrial Bases of Health Activism (Ken Shadlen, December 2007)

08-01 An Overview of Climate Change: What does it mean for our way of life? What is the best future we can hope for? (Neva Goodwin, March 2008)

08-02 Ecological Macroeconomics: Consumption, Investment, and Climate Change (Jonathan Harris, July 2008)

08-03 Policies for Funding a Response to Climate Change (Brian Roach, July 2008)

09-01 Resources, Rules and International Political Economy: The Politics of Development in the WTO (Kenneth C. Shadlen, January 2009)

09-02 Reforming and Reinforcing the Revolution: The Post-TRIPS Politics of Patents in Latin America (Kenneth C. Shadlen, April 2009)

09-03 Economic Writing on the Pressing Problems of the Day: The Roles of Moral Intuition and Methodological Confusion (Julie A. Nelson, April 2009)

09-04 Sociology, Economics, and Gender: Can Knowledge of the Past Contribute to a Better Future? (Julie A. Nelson, August 2008)

09-05 The Environmental Impacts of Soybean Expansion and Infrastructure Development in Brazil’s Amazon Basin (Maria del Carmen Vera-Diaz, Robert K. Kaufmann, and Daniel C. Nepstad, May 2009)

09-06 Between a Rock and a Soft Place: Ecological and Feminist Economics in Policy Debates (Julie A. Nelson, June 2009) 